\title{
Effect of Feeding Graded Levels of Pudina (Mentha arvensis) Leaf Powder on Egg Quality Traits in Laying Hens
}

\author{
K. Merina Devi ${ }^{1}$, Jyoti Palod ${ }^{1}$, Aashaq H. Dar ${ }^{1}$ and S. Shekhar ${ }^{2 *}$ \\ ${ }^{1}$ Department of Livestock Production Management, C.V.A.Sc., G.B.P.U.A.T, \\ Pantnagar - 263 145, Uttarakhand, India \\ ${ }^{2}$ Krishi Vigyan Kendra, Jainagar (ICAR-NRRI, Cuttack), Koderma, Jharkhand, India \\ *Corresponding author
}

\section{A B S T R A C T}

\section{Keywords}

Pudina, White Leghorn, Egg cholesterol, Designer eggs

Article Info

Accepted: 07 February 2018 Available Online: 10 March 2018
A feeding trial of 12 weeks duration was conducted to evaluate the effect of different levels of pudina leaf powder supplementation on egg quality traits in laying hens. A total number of 120 White leghorn laying hens of 36 weeks old were randomly assigned to 4 treatment groups (T1, T2, T3 and T4) with 6 replicates of 5 birds each. The basal diet was supplemented with pudina leaf powder containing $0,5.0,7.5$ and $10.0 \mathrm{~g} / \mathrm{kg}$ in dietary treatment groups respectively. The feeding trial was divided into phase I $\left(36^{\text {th }}-39^{\text {th }}\right.$ weeks $)$, phase II $\left(40^{\text {th }}-43^{\text {th }}\right.$ weeks $)$, phase III $\left(44^{\text {th }}-47^{\text {th }}\right.$ weeks $)$ and overall $\left(36^{\text {th }}-47^{\text {th }}\right.$ weeks $)$. At the end of each phase, egg quality and composition traits were studied. The results of the egg quality traits indicated that there were significant $(\mathrm{P}<0.05)$ improvement in egg weight, haugh unit and crude protein contents in the eggs of pudina added groups, whereas egg crude fat and cholesterol content were significantly $(\mathrm{P}<0.05)$ decreased with increased supplementation of pudina leaf powder. The overall best performance was shown at 10.0 $\mathrm{g} / \mathrm{kg}$ diet. Therefore, it can be concluded that the significant effect of pudina leaf powder supplementation on increase in egg weight, haugh unit, egg protein and decrease in crude fat and total cholesterol contents showed the major importance of pudina leaf powder in designer egg production.

\section{Introduction}

Egg is one of the most nutritious, unadulterated natural food which is accepted in all ages in human society with no religious taboo and hence has attained a vital place in human diet. Now a day's supplementation of herbs/ herbal preparations is done to boost performance of poultry by increasing growth rate, better feed conversion efficiency, greater livability, lower mortality, lower cost of egg and meat production, reduced risk of toxicity, minimum health hazards, environment friendliness and altered egg composition like reduced cholesterol level, increased protein level etc. to a considerable extent (Devegowda, 1996). One of these herbal plants used for curing illness since times immemorial is the common pudina, belongs to the genus Mentha and family Lamiaceae. Pudina (Mentha arvensis) is an erect herbacious perennial herb; the various sub- 
species of the herb usually grow $20 \mathrm{~cm}$ to 80 $\mathrm{cm}$ tall on square, hairy stem. Pudina have been used since ancient days across the world for the prevention and treatment of many diseases and is also broadly accepted and consumed as a spice and herbal medicine. It has a stimulant, tonic, anti-spasmodic, diaphoretic, stomachic, carminative, antibacterial, antifungal, antiviral and choleretic activities. Pudina contains menthol $(77.5-89.3 \%)$ as the main constituent, followed by menthone (0.3-7.9\%) and isomenthone (3.7-6.1\%) (Singh et al., 2005).

The literature survey unveiled that since there is limited number of scientific studies conducted on pudina ( $M$. arvensis) leaf powder supplementation on the effect of egg quality traits, the main purpose of this study was to determine the potential of the plant as a feed additive in laying hens by measuring its effect on the egg quality traits. Since, there is few literatures available on pudina (Mentha arvensis) on laying hens, comparative study was made with various plants of the Mentha species.

\section{Materials and Methods}

The experiment was conducted at Instructional Poultry Farm, C.V.A.Sc., Pantnagar (Uttarakhand). A total of 120 white leghorn laying hens of 36 weeks of age were randomly distributed in Californian cages in a completely randomized design (CRD). The laying hens were randomly divided into four treatment groups (T1, T2, T3 and T4) each with six replicates of five birds each and the replicates were equally distributed into upper and lower cage levels to minimize the cage level effect. Each hen was housed in a single cage. The basal diet was supplemented with pudina leaf powder containing 0, 5.0, 7.5 and $10.0 \mathrm{~g} / \mathrm{kg}$ in dietary treatment groups respectively. The feeding trial was divided into phase I $\left(36^{\text {th }}-39^{\text {th }}\right.$ weeks $)$, phase II $\left(40^{\text {th }}\right.$ - $43^{\text {th }}$ weeks $)$, phase III $\left(44^{\text {th }}-47^{\text {th }}\right.$ weeks $)$ and overall $\left(36^{\text {th }}-47^{\text {th }}\right.$ weeks $)$. The experimentation was carried out for 12 weeks. The egg quality traits were studied at the end of each phase. Two eggs from each replicate (48 eggs) were collected randomly for the last three consecutive days of each phase for analysis of egg quality traits in each phase. The composition of the egg was determined as per standard procedures (AOAC, 2005). At the end of each phase, two eggs from each replicates (48 eggs), consecutively for three days were collected carefully. The collected eggs were carefully broken and studied egg composition (crude protein, crude fat and ash) contents. The eggs were first boiled and shell and shell membranes were then removed carefully. The boiled eggs were chopped, transferred on previously weighed petridishes and kept in hot air oven at $70^{ \pm} 2^{0} \mathrm{C}$ for 24 hours and dried until no weight change was observed. Then the egg samples were kept in moisture free bags for further analysis of protein, fat and total ash. All statistical analysis was done with the help of SPSS procedure and the data obtained during the experiment was further evaluated using 1-way analysis of variance (ANOVA).

\section{Results and discussion}

It was observed from study that the increasing levels of pudina leaf powder supplementation in the feed $(5.0,7.5$ and $10.0 \mathrm{~g} / \mathrm{kg})$ of laying hens resulted significant increased $(\mathrm{P}<0.05)$ in egg weight (Table-3). Increased egg weight might be due to better utilization of nutrients by pudina leaf powder which in turn resulted in better egg weight. The results of the present study are in line with the findings of AbdelWareth and Lohakare (2014). They reported that supplementation of peppermint in laying hens improved egg weight due to the beneficial action of peppermint in the process of oviposition and also imperative effect on the conversion of digested feed into eggs. 
Table.1 Proximate analysis and nutritive value of dried Pudina (Mentha arvensis) leaf powder

\begin{tabular}{|l|l|}
\hline Chemical composition & Analyzed \\
\hline Dry matter & 98.10 \\
\hline Crude protein & 14.53 \\
\hline Crude fibre & 21.03 \\
\hline Crude fat & 2.95 \\
\hline Total ash & 9.38 \\
\hline Nitrogen free extract & 52.11 \\
\hline Calcium & 1.90 \\
\hline Phosphorus & 0.32 \\
\hline
\end{tabular}

Table.2 Ingredient and chemical composition (\% dry matter basis) of experimental basal diets used for laying chickens

\begin{tabular}{|l|c|}
\hline Ingredient & Percentage (\%) \\
\hline Maize & 53.00 \\
\hline Soyabean meal & 27.00 \\
\hline Deoiled rice bran & 8.80 \\
\hline Limestone powder & 9.00 \\
\hline Di calcium phosphate & 1.40 \\
\hline Common salt & 0.30 \\
\hline DL-methionine & 0.15 \\
\hline TM-premix & 0.10 \\
\hline Choline chloride & 0.15 \\
\hline Toxin binder & 0.05 \\
\hline Total & 100.00 \\
\hline Chemical composition $(\%)$ & Percent \\
\hline Dry matter & 90.79 \\
\hline Crude protein & 18.03 \\
\hline Ether extract & 2.52 \\
\hline Crude fibre & 5.78 \\
\hline Calcium & 3.87 \\
\hline Total ash & 12.00 \\
\hline Acid insoluble ash & 1.53 \\
\hline Total phosphorus & 0.73 \\
\hline Available phosphorus * & 0.40 \\
\hline Metabolisable energy (kcal/kg)* & 2601.38 \\
\hline Lysine * & 1.10 \\
\hline Methionine * & 0.48 \\
\hline Linoleic acid $*$ & 1.39 \\
\hline & \\
\hline & \\
\hline
\end{tabular}

*Calculated value:

${ }^{1}$ Trace mineral pre mix supplied (per kg diet): Magnesium- $300 \mathrm{mg}$, Manganese- $55 \mathrm{mg}$, Iodine- $0.4 \mathrm{mg}$, Iron- $56 \mathrm{~kg}$ diet): vitamin A-8250 IU, vitamin $\mathrm{D}_{3}-1200 \mathrm{ICU}$; vitamin $\mathrm{E}-40 \mathrm{IU}, \mathrm{mg}$; Zinc- $30 \mathrm{mg}$ and Copper $4 \mathrm{mg} .{ }^{2}$ Vitamin premix supplied (per vitamin K- $1 \mathrm{mg}$; vitamin $B_{1}-2 \mathrm{mg}$, vitamin $B_{2}-4 \mathrm{mg}$; niacin- $60 \mathrm{mg}$, pantothenic acid-10 mg, cyanocobalamin-10 microgram and choline-500 $\mathrm{mg}$. 
Table.3 Means \pm S.E. of egg quality traits of laying hens during phase wise

\begin{tabular}{|c|c|c|c|c|c|}
\hline Traits & Period & T1 & T2 & T3 & T4 \\
\hline \multirow[t]{4}{*}{ Egg weight (g) } & I Phase & $54.74 \pm 0.41$ & $55.40 \pm 0.24$ & $55.33 \pm 0.40$ & $55.81 \pm 0.53$ \\
\hline & II Phase ${ }^{*}$ & $55.15^{\mathrm{b}} \pm 0.40$ & $56.24^{\mathrm{ab}} \pm 0.54$ & $56.74^{\mathrm{a}} \pm 0.42$ & $56.88^{\mathrm{a}} \pm 0.28$ \\
\hline & III Phase* & $55.90^{\mathrm{b}} \pm 0.20$ & $56.41^{\mathrm{ab}} \pm 0.33$ & $56.88^{\mathrm{a}} \pm 0.38$ & $57.03^{a} \pm 0.24$ \\
\hline & Overall* & $55.30^{\mathrm{b}} \pm 0.20$ & $56.02^{a} \pm 0.16$ & $56.30^{\mathrm{a}} \pm 0.22$ & $56.55^{\mathrm{a}} \pm 0.15$ \\
\hline \multirow[t]{4}{*}{ Haugh Unit } & I Phase & $84.06 \pm 0.62$ & $84.03 \pm 0.87$ & $84.47 \pm 0.46$ & $85.04 \pm 0.42$ \\
\hline & II Phase & $84.77 \pm 0.94$ & $85.03 \pm 0.34$ & $85.18 \pm 0.40$ & $85.40 \pm 0.41$ \\
\hline & III Phase* & $85.15^{\mathrm{b}} \pm 0.42$ & $85.65^{\mathrm{ab}} \pm 0.37$ & $86.23^{\mathrm{a}} \pm 0.28$ & $86.62^{\mathrm{a}} \pm 0.20$ \\
\hline & Overall* & $84.66^{b} \pm 0.37$ & $84.90^{\mathrm{ab}} \pm 0.28$ & $85.30^{\mathrm{ab}} \pm 0.20$ & $85.70^{a} \pm 0.15$ \\
\hline
\end{tabular}

Table.4 Means \pm S.E. of egg quality traits of laying hens during overall experimental period $\left(36^{\text {th }}-47^{\text {th }}\right.$ weeks $)$

\begin{tabular}{|c|c|c|c|c|}
\hline Traits & T1 & T2 & T3 & T4 \\
\hline Shape index & $75.37 \pm 0.11$ & $75.50 \pm 0.14$ & $75.61 \pm 0.08$ & $75.74 \pm 0.12$ \\
\hline Albumen index & $8.87 \pm 0.17$ & $8.88 \pm 0.14$ & $8.93 \pm 0.10$ & $9.11 \pm 0.13$ \\
\hline Yolk index & $47.11 \pm 0.28$ & $47.17 \pm 0.32$ & $47.80 \pm 0.31$ & $47.60 \pm 0.16$ \\
\hline Shell thickness (mm) & $0.35 \pm 0.01$ & $0.36 \pm 0.01$ & $0.37 \pm 0.01$ & $0.37 \pm 0.01$ \\
\hline Albumen \% & $60.18 \pm 0.13$ & $60.27 \pm 0.10$ & $60.34 \pm 0.09$ & $60.42 \pm 0.13$ \\
\hline Yolk \% & $30.22 \pm 0.20$ & $30.32 \pm 0.08$ & $30.38 \pm 0.10$ & $30.40 \pm 0.15$ \\
\hline Shell weight \% & $9.40 \pm 0.16$ & $9.41 \pm 0.15$ & $9.42 \pm 0.11$ & $9.35 \pm 0.21$ \\
\hline Yolk/ Albumin ratio & $49.91 \pm 0.34$ & $50.30 \pm 0.14$ & $50.33 \pm 0.17$ & $50.37 \pm 0.23$ \\
\hline
\end{tabular}

Values with different superscripts row wise differ significantly $(\mathrm{P}<0.05)$

Table.5 Means \pm S.E. of egg composition traits of laying hens during overall experimental period $\left(36^{\text {th }}-47^{\text {th }}\right.$ weeks $)$

\begin{tabular}{|c|c|c|c|c|c|}
\hline Traits & Period & T1 & T2 & T3 & T4 \\
\hline \multirow[t]{4}{*}{ Total ash (\%) } & I Phase & $4.81 \pm 0.15$ & $5.10 \pm 0.05$ & $4.90 \pm 0.06$ & $4.83 \pm 0.06$ \\
\hline & II Phase & $5.18 \pm 0.15$ & $5.23 \pm 0.13$ & $5.10 \pm 0.04$ & $5.05 \pm 0.05$ \\
\hline & III Phase & $4.92 \pm 0.13$ & $5.08 \pm 0.18$ & $5.22 \pm 0.15$ & $5.19 \pm 0.06$ \\
\hline & Overall & $4.98 \pm 0.30$ & $5.11 \pm 0.26$ & $5.07 \pm 0.18$ & $5.02 \pm 0.12$ \\
\hline \multirow[t]{4}{*}{ Crude fat (\%) } & I Phase & $43.49 \pm 0.07$ & $43.42 \pm 0.05$ & $43.44 \pm 0.07$ & $43.31 \pm 0.12$ \\
\hline & II Phase & $43.43 \pm 0.07$ & $43.33 \pm 0.08$ & $43.35 \pm 0.11$ & $43.08 \pm 0.13$ \\
\hline & III Phase* & $43.45^{\mathrm{a}} \pm 0.23$ & $43.23^{\mathrm{ab}} \pm 0.10$ & $42.96^{b} \pm 0.08$ & $42.92^{b} \pm 0.14$ \\
\hline & Overall* & $43.46^{\mathrm{a}} \pm 0.10$ & $43.33^{\mathrm{ab}} \pm 0.06$ & $43.25^{\mathrm{ab}} \pm 0.07$ & $43.10^{c} \pm 0.11$ \\
\hline \multirow[t]{4}{*}{ Crude protein (\%) } & I Phase & $44.12 \pm 0.17$ & $44.24 \pm 0.30$ & $44.34 \pm 0.30$ & $44.67 \pm 0.18$ \\
\hline & II Phase* & $44.36^{\mathrm{b}} \pm 0.20$ & $44.59^{\mathrm{ab}} \pm 0.17$ & $44.66^{\mathrm{ab}} \pm 0.12$ & $44.98^{\mathrm{a}} \pm 0.11$ \\
\hline & III Phase & $44.68 \pm 0.15$ & $44.87 \pm 0.23$ & $44.93 \pm 0.13$ & $45.07 \pm 0.13$ \\
\hline & Overall* & $44.39^{b} \pm 0.12$ & $44.58^{\mathrm{ab}} \pm 0.15$ & $44.62^{\mathrm{ab}} \pm 0.13$ & $44.91^{\mathrm{a}} \pm 0.05$ \\
\hline \multirow{4}{*}{$\begin{array}{l}\text { Egg cholesterol } \\
\text { (mg/g yolk) }\end{array}$} & I Phase & $12.31 \pm 0.06$ & $12.28 \pm 0.12$ & $12.22 \pm 0.05$ & $12.13 \pm 0.11$ \\
\hline & II Phase & $12.35 \pm 0.07$ & $12.15 \pm 0.13$ & $12.08 \pm 0.05$ & $11.95 \pm 0.13$ \\
\hline & III Phase* & $12.28^{\mathrm{a}} \pm 0.06$ & $11.96^{\mathrm{a}} \pm 0.17$ & $11.41^{\mathrm{b}} \pm 0.13$ & $11.45^{b} \pm 0.11$ \\
\hline & Overall* & $12.31^{\mathrm{a}} \pm 0.03$ & $12.13^{b} \pm 0.07$ & $11.90^{c} \pm 0.05$ & $11.85^{c} \pm 0.04$ \\
\hline
\end{tabular}

Values with different superscripts column wise differ significantly $(\mathrm{P}<0.05)$ 
Pudina leaf powder supplementation in the feed @ $10.0 \mathrm{~g} / \mathrm{kg}$ in feed of laying hens resulted significant increased $(\mathrm{P}<0.05)$ in haugh unit (Table 3). Similar findings were recorded by Sayedpiran et al., (2011) AbdeiWareth and Lohakare (2014). No significant difference in albumen and yolk percentages among different treatment groups in any of the phase of trial. Similarly, shape index, albumen index, shell thickness, shell weight and yolk/albumen ration etc., in all phases and in overall period (Table 4) were not affected by supplementation of pudina leaf powder. Total ash content in egg did not show significant difference among different treatment groups in any phase including overall period. Significantly lower egg fat per cent and cholesterol content of was recorded in birds of group T3 and T4 (Table 5). As serum cholesterol is the precursor for egg yolk cholesterol, reduction in egg yolk cholesterol might be related to reduction in serum cholesterol. These findings indicate that there is positive correlation between serum cholesterol and egg cholesterol values. Similar results were obtained by Lim et al., 2006 and Yin et al., (2008). Significant $(\mathrm{P}<0.05)$ increase of egg crude protein in $\mathrm{T} 4$ group (44.98 \pm 0.11$)$ during phase II and overall trial periods reflexed the beneficial effect of pudina. The increased protein of eggs might be due to the possible reason that pudina supplementation enhances absorption of amino acid and thereby increase protein synthesis. This may be attributed to better utilization of protein by pudina leaf powder supplementation. The result of present study also indicated that there is positive correlation between serum protein and egg protein levels due to the supplementation of pudina leaf powder.

The effect of 12 weeks supplementation of pudina leaf powder showed increased egg weight, haugh unit, egg crude protein and decrease egg fat and cholesterol contents indicating the importance of pudina in designer egg production. The overall best performance was shown at $10.0 \mathrm{~g} / \mathrm{kg}$ diet. The addition of pudina to the diet of laying hens as performance booster could be a promising alternative to the use of synthetic products in egg production. More detailed studies are essential in future to determine the optimal and safety dietary inclusion and its economic impact.

\section{Acknowledgment}

The authors are thankful to Dr. D.V. Singh, Professor and Head, Department of LPM, and the departments of Veterinary Animal Nutrition and Animal Genetics and Breeding, GBPUA\&T, Pantnagar for providing necessary facilitates for conducting the research activity.

\section{References}

Abdel-Wareth, A. A. and Lohakare, J. D. 2014. Effect of dietary supplementation of peppermint on performance, egg quality, and serum metabolic profile of Hy-Line Brown hens during the late laying period. Animal Feed Science and Technology. 197: 114-120.

AOAC, 2005. Animal feeds. Official Methods of Analysis, $18^{\text {th }}$ ed., AOAC International, Maryland, USA.

Devegowda, G. 1996. Herbal medicines, an untapped treasure in poultry production. In: Proc. $20^{\text {th }}$ World Poult. Congr. New Delhi, India.

Lim, K.S., Vou, S.J., An, B.K. and Kang, C.W. 2006. Effects of dietary garlic powder and copper on cholesterol content and quality characteristics of chicken eggs. Asian-Australian Journal of Animal Science. 19: 582-86.

Sadi, I.C., Bayram, I., Akkaya, A. B., Uyarlar, C. and Yardimci, M. 2008. Effect of peppermint (Mentha piperita) on 
performance, hatchability and egg quality parameters of laying quail (Corturnix cortunix japonica). Journal of Animal and Vet Advances. 7: 148994.

Sayedpiran, S.A., Nobakht, A. and Khodaei, S. 2011. The effects of using probiotic, organic acid and blends of some medicinal herbs on performance, egg quality, blood biochemical and immunity parameters of laying hens. Tabriz Veterinary Journal. 5: 1111-22.

Singh, A.K., V.K., Raina, Naqvi, A.A., Patra, N.K., Birendra, K., Ram, P. and
Khanuja, S.P.S. 2005. Essential oil composition and chemoarrays of menthol mint (Mentha arvensis L. $\mathrm{f}$. piperascens Malinvaud ex. Holmes) cultivars. Flav. Flagr. J. 20:302-305. Guan, Y.F. and Wang, Z.Y. 2008 Effects of dietary conjugated linoleic acid on the fatty acid profile and cholesterol content of egg yolks from different breeds of layers. Poultry Science.87: 284-90.

\section{How to cite this article:}

Merina Devi K., Jyoti Palod, Aashaq H. Dar and Shekhar S. 2018. Effect of Feeding Graded Levels of Pudina (Mentha arvensis) Leaf Powder on Egg Quality Traits in Laying Hens. Int.J.Curr.Microbiol.App.Sci. 7(03): 756-761. doi: https://doi.org/10.20546/ijcmas.2018.703.088 